\title{
Evaluation of methods for estimating energy performance of biogas production
}

\author{
J. Havukainen ${ }^{\text {a,*, V. Uusitalo }}{ }^{\text {a }}$, A. Niskanen ${ }^{\text {a }}$, V. Kapustina ${ }^{a}$, M. Horttanainen ${ }^{\text {a }}$. \\ ${ }^{a}$ Lappeenranta University of Technology, Laboratory of Environmental Engineering. \\ P.O. Box 20, FI-53851, Lappeenranta, Finland \\ * Corresponding author. Tel.: +358 40 5848385; fax: +358 56216399 ; \\ E-mail: jouni.havukainen@lut.fi
}

\begin{abstract}
This study focused on identifying various system boundaries and evaluating methods of estimating energy performance of biogas production. First, the output-input ratio method used for evaluating energy performance from the system boundaries was reviewed. Secondly, ways to assess the efficiency of biogas use and parasitic energy demand were investigated. Thirdly, an approach for comparing biogas production to other energy production methods was evaluated. Data from an existing biogas plant, located in Finland, was used for the evaluation of the methods. The results indicate that calculating and comparing the output-input ratios $\left(\mathrm{R}_{\mathrm{pr} 1}, \mathrm{R}_{\mathrm{pr} 2}, \mathrm{R}_{\mathrm{ut}}, \mathrm{R}_{\mathrm{pl}}\right.$ and $\left.\mathrm{R}_{\mathrm{sy}}\right)$ can be used in evaluating the performance of biogas production system. In addition, the parasitic energy demand calculations (w) and the efficiency of utilizing produced biogas $(\eta)$ provide detailed information on energy performance of the biogas plant. Furthermore, $R_{f}$ and energy output in relation to total solid mass of feedstock $\left(\mathrm{F}_{\mathrm{O} / \mathrm{TS}}\right)$ are useful in comparing biogas production with other energy recovery technologies. As a conclusion it is essential for the comparability of biogas plants that their energy performance would be calculated in a more consistent manner in the future.
\end{abstract}

\section{Keywords}

Biogas; energy performance; waste management; energy efficiency

\section{Introduction}

In the EU, the target for the share of renewable energy in overall energy consumption is $20 \%$ by 2020 . The target for the share of renewable energy in transport is $10 \%$ by then. Energy efficiency should also be improved by $20 \%$. At the moment, $9 \%$ of total energy consumption is renewable (Eurostat, 2011). Biogas aids in achieving renewable energy goals: it may be used in energy production, and with upgrading, in transport. Biogas production can also be helpful in finding a way for utilizing biodegradable municipal waste. The EU Landfill Directive states that the deposition of biodegradable municipal waste into landfills must be reduced to 50\% of the mass deposited in 1995 by 2020 .

Biogas production has undergone extensive research, resulting in a multitude of research papers dealing with such topics as biogas production (Banks et al., 2011; Prade et al., 2012), the improvement of biogas production (Ward et al., 2008), and different process configurations (Poeschl et al., 2012). The biogas process has been recognized as a potential and eco-friendly utilization of biodegradable waste.

Energy efficiency of Finnish biogas plants has not received much attention in Finland, because most of the revenue of the large-scale plants comes from the gate fees (the fees paid by the waste management company to the biogas plant for the waste deposited). 
Indeed, the gate fees can account for $90 \%$ of the income that the plant receives. Income from energy products has not played a significant role in the economics of the plant. However, in the future, plants will strive to improve energy efficiency and produce more energy products (e.g. biomethane) as well as different nutrient products. This is partially due to the feed-in tariff policy mechanism for rewarding produced renewable energy.

Determining the energy efficiency of a biogas plant requires a calculation of the energy balance. The parasitic energy demand of digestion plants varies significantly in the literature. Laaber et al. 2007 examined 27 biogas plants in Austria, and the median for the parasitic electricity consumption was determined to be $2.66 \%$ of the biogas energy. The median for the annual efficiency of the biogas plants (the sum of produced electricity and used heat divided by the biogas energy) was $47.8 \%$; for the annual thermal efficiency, $14.9 \%$; and for the annual electrical efficiency, $31.3 \%$ in relation to biogas energy. The low annual efficiency was found to be chiefly due to the low use of produced heat. Banks et al. 2011 found that the net energy from anaerobic digestion of food waste was 405 $\mathrm{kWh} / \mathrm{t}$ wet weight, and that parasitic electricity and heat demands were $30 \%$ of the produced electricity and heat energy. Murphy et al. IEA Bioenergy Task 37, 2011 presented an energy crop digestion plant with a calculated net electrical efficiency of $37 \%$ from the energy content of the original substrate, and with a high heat loss of $50.9 \%$ compared to the used heat of $7.8 \%$.

\subsection{The challenges in estimating biogas production energy performance}

The purpose behind calculating the energy efficiency of power production is to estimate how well the conversion process uses the energy content of the fuel. Efficiency is important for keeping the fuel costs down and emissions of power production low. In most energy production cases, energy efficiency is defined in relation to input energy. The input energy includes fuel energy when one calculates energy efficiency for combustion. In the European standards, fuel energy is calculated by using the lower heating value as a received basis (including moisture) ( $\left.\mathrm{LHV}_{\mathrm{ar}}\right)$. Direct and indirect methods for calculating the efficiency of water tube boilers are included in Standard EN 12952-15. In the case of the direct method, energy efficiency is defined as the heat absorbed divided by the heat input. The indirect method includes an examination of all accountable heat losses, and the efficiency is then defined as one subtracted by heat losses and divided by heat input.

As with efficiency calculations of other power production methods, the reason for defining the energy performance of biogas production is to obtain information about the effectiveness of a biogas plant in transferring the energy content of feedstock to useful energy carriers. Challenges emerge in the defining of the energy content of incoming material; for example, $\mathrm{LHV}_{\mathrm{ar}}$ is not useful in calculating the energy content of wet feedstock used in biogas production, since it can be negative. One solution to this could be to define the maximum biogas yields in the laboratory.

\subsection{Energy performance evaluation methods from the literature}

Biogas plant energy performance has been calculated by different methods in the literature (Table 1). The most commonly used method of estimating energy performance 
is calculating the output-input ratio by dividing the output energy with the energy input for different operations. Most of the output-input ratios also include the energy use in crop production and the collection of waste from waste material. Indirect energy (energy used to produce materials) is in most cases excluded from the input energy. One exception to this is the research conducted by Salter \& Banks 2009. They included the indirect energy used for production of fertilizers, machines and buildings.

Table 1. Energy performance calculation methods used in the literature.

\begin{tabular}{|c|c|c|c|}
\hline Method & Included & Result & Reference \\
\hline Input/output 1 & $\begin{array}{l}\text { Input: Primary energy for obtaining raw material, } \\
\text { transport, operation of biogas plant Output: Biogas } \\
\text { energy content }\end{array}$ & $20-40 \%$ & $\begin{array}{l}\text { (Berglund } \\
\text { and } \\
\text { Börjesson, } \\
\text { 2006) }\end{array}$ \\
\hline Input/output 2 & $\begin{array}{l}\text { Input: Crop cultivation, collection, transport, biogas } \\
\text { plant operation, digestate processing Output: Energy } \\
\text { produced from biogas }\end{array}$ & $10.5-64 \%$ & $\begin{array}{l}\text { (Pöschl et } \\
\text { al., 2010) }\end{array}$ \\
\hline Input/output 3 & $\begin{array}{l}\text { Input: Production of inputs, cultivation, digestion, } \\
\text { biogas processing and transport fuel delivery Output: } \\
\text { Biomethane energy }\end{array}$ & $22-37 \%$ & $\begin{array}{l}\text { (Tuomisto } \\
\text { and } \\
\text { Helenius, } \\
\text { 2008) }\end{array}$ \\
\hline Output/input 1 & $\begin{array}{l}\text { Output: Energy produced from biogas } \\
\text { Input: direct and indirect energy for cultivation, } \\
\text { harvesting, transport, conversion, digestate spreading }\end{array}$ & $2.6-2.7$ & $\begin{array}{l}\text { (Prade et al., } \\
\text { 2012) }\end{array}$ \\
\hline Output/input 2 & $\begin{array}{l}\text { Output: Energy content of biogas Input: energy for } \\
\text { cultivation, harvest and transport }\end{array}$ & $6.8-13.1$ & $\begin{array}{l}\text { (Uellendahl } \\
\text { et al., 2008) }\end{array}$ \\
\hline Output/input 3 & $\begin{array}{l}\text { Output: biogas energy Input: Crop cultivation } \\
\text { transport, digester, digestate disposal }\end{array}$ & $2.1-3.9$ & $\begin{array}{l}\text { (Gropgen, } \\
2007)\end{array}$ \\
\hline Output/input 4 & $\begin{array}{l}\text { Output: Biomethane Input: Crop production, } \\
\text { transport, fertilizer and pesticides }\end{array}$ & $7-25$ & $\begin{array}{l}\text { (Gerin et al., } \\
2008)\end{array}$ \\
\hline Output/input 5 & $\begin{array}{l}\text { Output: Heat, power and biomethane } \\
\text { Input: Crop production, transport, biogas production } \\
\text { and upgrading }\end{array}$ & $3.5-8.2$ & $\begin{array}{l}\text { (Seppälä et } \\
\text { al., 2008) }\end{array}$ \\
\hline Output/input 6 & $\begin{array}{l}\text { Output: Heat, power and biomethane } \\
\text { Input: Crop production and digestion, biogas and } \\
\text { digestate use (direct and indirect energy) }\end{array}$ & $1.8-3.3$ & $\begin{array}{l}\text { (Salter and } \\
\text { Banks, } \\
\text { 2009) }\end{array}$ \\
\hline Output/input 7 & $\begin{array}{l}\text { Output: Heat, power and biomethane } \\
\text { Input: Crop production and processing, reactor }\end{array}$ & $4.04-6.5$ & $\begin{array}{l}\text { (Salter et } \\
\text { al., 2005) }\end{array}$ \\
\hline Output/input 8 & $\begin{array}{l}\text { Output: Electricity and heat Input: Cultivation, } \\
\text { harvesting, digestion, digestate }\end{array}$ & $5.5-6.8$ & $\begin{array}{l}\text { (Navickas et } \\
\text { al., 2012) }\end{array}$ \\
\hline $\begin{array}{l}\text { Biomethane } \\
\text { yield (BMY) }\end{array}$ & $\begin{array}{l}\mathrm{BMY}_{1}=(\text { methane potential of input biomass - } \\
\text { methane potential of the digestate)/ methane potential } \\
\text { of the input biomass. } \\
\mathrm{BMY}_{2}=\text { effective specific methane produced / } \\
\text { biomethane potential of input }\end{array}$ & $\begin{array}{l}\mathrm{BMY}_{1} \\
\text { and } \\
\mathrm{BMY}_{2} 84- \\
93 \%\end{array}$ & $\begin{array}{l}\text { (Schievano } \\
\text { et al., 2011) }\end{array}$ \\
\hline $\begin{array}{l}\text { Energy } \\
\text { efficiency }\end{array}$ & $\begin{array}{l}\text { Mechanical energy of tractor/(biogas energy + energy } \\
\text { produced outside system e.g. electricity, diesel) }\end{array}$ & $5.8-13 \%$ & $\begin{array}{l}\text { (Lacour et } \\
\text { al., 2012) }\end{array}$ \\
\hline $\begin{array}{l}\text { Relative biogas } \\
\text { yield }\end{array}$ & $\begin{array}{l}\text { Theoretical and measured biogas yield, volumetric } \\
\text { productivity, total and theoretical electricity } \\
\text { production, own energy consumption }\end{array}$ & $\begin{array}{l}\text { Relative } \\
\text { biogas } \\
\text { yield } 90- \\
161 \%\end{array}$ & $\begin{array}{l}\text { (Djatkov et } \\
\text { al., 2012) }\end{array}$ \\
\hline $\begin{array}{l}\text { Total annual } \\
\text { efficiency }\end{array}$ & (produced electricity + used heat)/ fuel energy & $30.5-73 \%$ & $\begin{array}{l}\text { (Laaber et } \\
\text { al., 2007) }\end{array}$ \\
\hline Electricity use & $\begin{array}{l}\text { Electricity use (Combined Heat and Power }(\mathrm{CHP})+ \\
\text { rest of the plant)/produced electricity }\end{array}$ & $30.4 \%$ & $\begin{array}{l}\text { (Banks et } \\
\text { al., 2011) }\end{array}$ \\
\hline
\end{tabular}


There is no single widely used method for estimating the energy efficiency of biogas plants. Both energy output divided by energy input (output/input) (Patterson, 1996; Tanaka, 2008; Prade et al., 2012) and energy input divided by energy output (Pöschl et al., 2010) ratios have been used in estimating energy efficiency. The definition of input and output energies also varies among the studies. For example, Berglund \& Börjesson 2006 used the sum of energy into the biogas system as input and the biogas energy content as output when calculating the input-output ratio, whereas Pöschl et al. 2010 assessed process energy efficiency with the primary energy input to output (PEIO) ratio. Pöschl et al. 2010 included crop cultivation and feedstock pre-treatment, feedstock collection and transport, biogas plant operation, biogas utilization, and digestate processing and handling in the input energy. Output was then the sum of the potential energy conversion from the biogas. PEIO was also used in a more recent study by Poeschl et al. 2012. Generally, in the case of a given input-output ratio, the lower the ratio is, the higher the energy efficiency is.

Other definitions for estimating biogas production efficiency exist. Lacour et al. 2012 calculated the energy efficiency of a biogas fuelling system as useful mechanical energy delivered by tractor divided by the sum of biogas energy and incoming energy to the system. They also defined the coefficient of performance (COP) as a ratio of mechanical energy delivered by tractor to incoming energy. In addition to technological parameters, Laaber et al. 2007 included economic, socio-economic and environmental parameters in the DEA evaluation of biogas plants. Cao \& Pawlowski 2012 compared energy efficiency of sewage sludge pyrolysis to anaerobic digestion of sewage sludge followed by pyrolysis with a ratio of energy content of products to the higher heating value of dry material $\left(\mathrm{HHV}_{\mathrm{d}}\right)$ of the sludge. Djatkov et al. 2012 rated the overall efficiency of biogas plant by combining the results of four aspects of the biogas plant performance: biogas production, biogas utilization, environmental impacts and socio-economic efficiency. Davis et al. 2009 presented a fuel energy ratio (FER), a ratio of the fuel energy produced in relation to the used fossil fuel energy, which could be employed for defining energy efficiency. They found a range of 0.44-5.60 when studying the literature.

It is evident that a coherent and comprehensive way for analyzing biogas plant energy efficiency is lacking in the literature. The reason might stem from lack of standard for defining the energy efficiency of biogas production. The method of the input-output or output-input ratio has primarily been used, but it is not always clear what is included in the system boundary. The definition of clear system boundary is vital since the input as well as output energies are defined by it. The aim of this study is to illustrate the different system boundaries that could be used in energy performance evaluation and to evaluate different methods for defining energy performance of biogas production.

\section{Materials and methods}

\subsection{Defining system boundary}

The reason for forming system boundaries around a system is to examine the input and outputs from this system through the system boundary as well as possible storing inside the system boundaries. Defining energy performance necessitates defining the system boundary. The system boundary in turn determines the selected system to be examined, 
therefore affecting the results of a study. There are several different system boundaries that may be used in estimating the energy performance of a biogas plant (Gropgen, 2007) (Prade et al., 2012) (Pöschl et al., 2010). Biogas production and biogas utilization can be estimated separately. In doing this, one obtains information on both processes separately. In addition, estimating the whole biogas plant system boundary yields information on the energy performance of the plant as an energy production facility. The widest system boundary for biogas production should also include the obtaining of the masses, i.e. collection and transport of biowaste and cultivation; and harvesting and transport of agricultural feedstock (Pöschl et al., 2010). The system boundaries used for estimating energy performance in this study are presented in Figure 1.

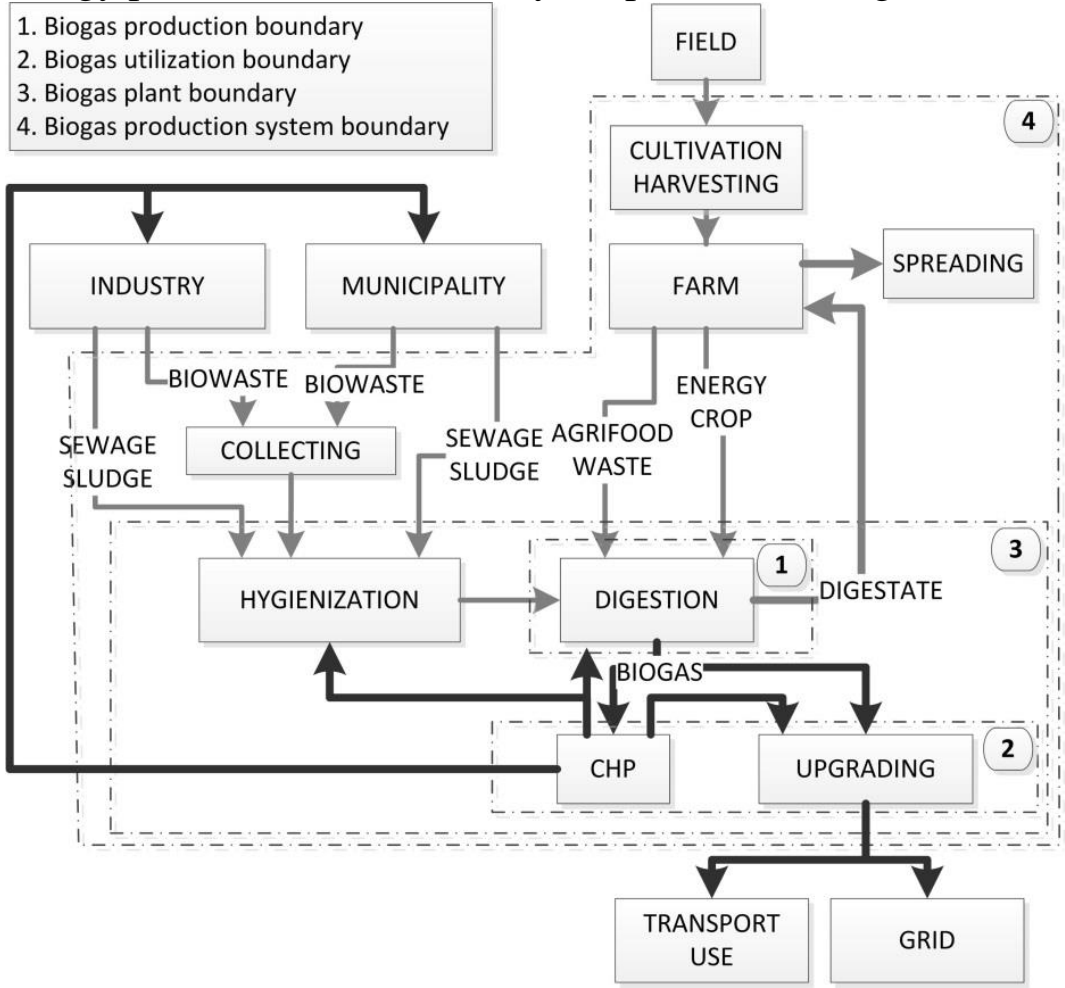

Figure 1. Biogas production system.

\subsection{Energy performance calculation}

\subsubsection{Output-input ratio}

The output-input ratio has been defined for biogas plant energy performance calculations as the ratio of produced energy to the energy used in the example biogas system (Table 1) (Salter et al., 2005; Salter and Banks, 2009; Gerin et al., 2008; Gropgen, 2007; Uellendahl et al., 2008; Prade et al., 2012; Seppälä et al., 2008). In this study, the outputinput ratio $(\mathrm{R})$ is used to estimate the energy performance of biogas production with different system boundaries. The energy content of the solid materials and indirect energy included in fertilizer production and buildings are excluded.

Energy performance can be defined for biogas production alone by considering the feedstock coming to the plant as the input and the biogas as an output of the plant. The main difficulty resides in defining the energy content of feedstock, because the lower heating value $\left(\mathrm{LHV}_{\mathrm{ar}}\right)$ can be negative for wet feedstock. 
One may also focus on the capability of the biogas reactor for obtaining the full biogas potential out of the feedstock source. Efficiency could then be defined as the relation of the difference of biogas yield of feedstock and digestate to the biogas yield of the feedstock (Schievano et al., 2011). Most of the uncertainties of this approach concern the defining of the biogas yield of the feedstock. In co-treatment, when one calculates the total yield of feedstock, the use of individual biogas yields for waste fractions is problematic, because the co-treatment can result in a higher or lower biogas potential than expected (Pöschl et al., 2010). Laboratory tests can be conducted for the feedstocks, but if measured values are not available, yields found from the literature can be used. However, when one implements the literature values, a range of yields should be utililized in order to find the minimum and maximum values for the energy efficiency.

Schievano et al. 2011 have suggested a biomethane yield (BMY) technique for measuring the efficiency of full-scale biogas plants. $\mathrm{BMY}_{1}$ is calculated as the difference of the methane potential of input biomass and the methane potential of the digestate divided by the methane potential of the input biomass. $\mathrm{BMY}_{2}$ is defined as the effective specific methane produced (SMP, $\mathrm{m}^{3} / \mathrm{kg}_{\mathrm{TS}}$ ) divided by the biomethane yield of input $\left(\mathrm{BMP}_{\text {in }}\right.$ $\mathrm{m}^{3} / \mathrm{kg}_{\mathrm{TS}}$ ). Here the output-input ratio is defined as the relation of the produced biogas energy to the biogas yield of feedstocks:

$R_{p r 1}=\frac{E_{b g}}{\sum_{i=1}^{n} m_{i, T S^{*} Y_{b g, i} * L H V_{C H 4}}}$

where $E_{b g}$ is the energy content of the produced biogas (MWh), $\mathrm{m}_{\mathrm{i}}$ is the total solid (TS) in feedstock $i(t), Y_{b g, i}$ is the methane yield of feedstock $i\left(\mathrm{~m}^{3} / \mathrm{t}_{\mathrm{TS}}\right)$ and $\mathrm{LHV}_{\mathrm{CH} 4}$ is the lower heating value of methane $\left(0.010 \mathrm{MWh} / \mathrm{m}^{3}\right)$. The number of feedstocks is $\mathrm{n}$. The maximum value of $\mathrm{R}_{\mathrm{pr} 1}$ is one.

Another approach one may take to assess biogas production energy performance is to calculate the output-input ratio as a relation of produced biogas to the parasitic electricity and heat:

$R_{\text {pr2 }}=\frac{E_{b g}}{E_{\text {el,par }}+E_{h, p a r}}$

where $\mathrm{E}_{\mathrm{el}, \mathrm{par}}$ is the parasitic electricity used for biogas production (MWh), and $\mathrm{E}_{\mathrm{h}, \mathrm{par}}$ is the parasitic heat needed in biogas production processes (MWh).

Laaber et al. 2007 have defined annual efficiency as the ratio of produced energy to used biogas. However, this could also be viewed as the output-input ratio of biogas utilization $\left(\mathrm{R}_{\mathrm{ut}}\right)$, where the selected system boundary defines what the output energy is. In the definition of annual efficiency, the heat energy could be defined as used heat energy, which would mean that only the used heat is accounted for. In the $\mathrm{R}_{\mathrm{ut}}$ defined according to Figure 1, the system boundary is drawn so that the heat energy connotes the heat coming from energy production systems using biogas; therefore, $R_{u t}$ describes the ability of the biogas utilization system to produce energy from biogas.

$R_{u t}=\frac{E_{e l, p r o d}+E_{h, p r o d}+E_{b m}-E_{e l, p a r, C H P}-E_{e l, p a r, u p}-E_{h, p a r, u p}}{E_{b g}}$

where $\mathrm{E}_{\mathrm{el}, \text { prod }}$ is the produced electricity $(\mathrm{MWh}), \mathrm{E}_{\mathrm{h}, \text { prod }}$ is the produced heat $(\mathrm{MWh}), \mathrm{E}_{\mathrm{bm}}$ is the energy content of produced biomethane $(\mathrm{MWh}), \mathrm{E}_{\text {el,par,CHP }}$ is the parasitic electricity need of the (CHP) equipment $(\mathrm{MWh}), \mathrm{E}_{\mathrm{el} \text {,par,up }}$ is the parasitic electricity need of the upgrading process $(\mathrm{MWh})$ and $\mathrm{E}_{\mathrm{h} \text {,par,up }}$ is the parasitic heat need of the upgrading process (MWh). The maximum value of $\mathrm{R}_{\mathrm{ut}}$ is one. 
The ratio of exported and imported energy flows through the system boundary 3 in Figure 1 can be defined as the output-input ratio of the biogas plant $\left(\mathrm{R}_{\mathrm{pl}}\right)$.

$R_{p l}=\frac{E_{h, s}+E_{b m}+E_{e l, s}}{E_{e l, p a r, p l}+E_{f}+E_{h, \mathrm{par}, \mathrm{pl}}}$

where $E_{f}$ is the energy content of other fuels used in the production of energy in the biogas plant, $\mathrm{E}_{\mathrm{h}, \mathrm{s}}$ is the heat energy supplied to processes outside the biogas plant boundary, $\mathrm{E}_{\mathrm{el}, \mathrm{s}}$ is the electricity supplied to the grid, $E_{\mathrm{el}, \mathrm{par}, \mathrm{pl}}$ is the electricity need from the electricity grid and $\mathrm{E}_{\mathrm{h}, \mathrm{par}, \mathrm{pl}}$ is the heat need from outside the biogas plant.

The output-input ratio for a given biogas production system has been extensively used in evaluating biogas production from energy crops in particular (Salter et al., 2005; Salter and Banks, 2009; Gerin et al., 2008; Gropgen, 2007; Uellendahl et al., 2008; Prade et al., 2012; Seppälä et al., 2008). The input energy includes the obtaining and transport of the masses to the biogas plant as well as the transport and utilization of the digestate. In the case of waste materials, collection and transport are included, and in that of energy crops, cultivation and harvesting inputs as well as transport to the biogas plant are included.

The output-input ratio $\left(\mathrm{R}_{\mathrm{sy}}\right)$ for a biogas production system reflects the system boundary 4 in Figure 1.

$R_{s y}=\frac{E_{h, s}+E_{b m}+E_{e l, s}}{E_{t, d}+E_{t, f s}+E_{c h}+E_{c}+E_{s d}+E_{e l, o}+E_{f}+E_{h, o}}$

where the fuel need is $\mathrm{E}_{\mathrm{t}, \mathrm{d}}$ for transporting the digestate $(\mathrm{MWh}), \mathrm{E}_{\mathrm{sd}}$ for spreading the digestate $(\mathrm{MWh}), \mathrm{E}_{\mathrm{t}, \mathrm{fs}}$ for transporting the feedstock $(\mathrm{MWh}), \mathrm{E}_{\mathrm{c}}$ for the collection of biowaste (MWh) and $\mathrm{E}_{\mathrm{ch}}$ for the cultivation and harvesting of the energy crop (MWh).

\subsubsection{The biogas plant's parasitic energy consumption}

In addition to the output-input ratios defined for the system boundary, one needs to obtain information on the parasitic energy need and efficiency of energy conversion systems in order to evaluate the energy performance of the biogas plant. The parasitic energy use in relation to the produced energy is useful for comparing the parasitic energy needs of different plants. The parasitic energy can be proportioned to either the produced energy or the produced biogas. For example, Banks et al. 2011 assigned parasitic electricity use in relation to produced electricity, and Laaber et al. 2007 did so in relation to produced biogas.

Equation 6 describes the parasitic electricity demand in relation to the produced electricity, and equation 7 describes the demand in relation to biogas energy. Equations 8 and 9 can be similarly defined for parasitic heat demand.

$$
\begin{aligned}
& w_{\text {el,par } 1}=\frac{E_{\text {el,par }}}{E_{\text {el,prod }}} \\
& w_{\text {el,par } 2}=\frac{E_{\text {el,par }}}{E_{\text {bg }}} \\
& w_{h, \text { par } 1}=\frac{E_{h, \text { par }}}{E_{h, \text { prod }}} \\
& w_{h, \text { par } 2}=\frac{E_{h, \text { par }}}{E_{b g}}
\end{aligned}
$$




\subsubsection{Energy efficiency of power production from biogas}

The standard way of defining total electricity and heat efficiency in power plants is to divide the produced energy by the used fuel energy. In the case of energy production from biogas, the biogas is already a product from waste materials, so the usual efficiency definition does not describe the efficiency of whole process, but rather only describes the efficiency of utilizing produced energy. Laaber et al. 2007, Eastern Research Group 2011 and Banks et al. 2011 have used biogas production electric efficiency. In addition, Banks et al. 2011 have made a distinction between net electric efficiency, when the parasitic electricity of CHP is subtracted, and gross electric efficiency, when it is not. Gross electric efficiency, net electric efficiency and thermal efficiency of $\mathrm{CHP}$ are calculated in equations 11,12 and 13 , respectively.

$\eta_{C H P, \text { el gross }}=\frac{E_{e l, p r o d}}{E_{b g, C H P}}$

$\eta_{C H P, \text { el net }}=\frac{E_{e l, p r o d}-E_{e l, p a r, C H P}}{E_{b g, C H P}}$

where and $\mathrm{E}_{\mathrm{bg}, \mathrm{CHP}}$ is the energy of the biogas going to $\mathrm{CHP}(\mathrm{MWh})$.

$\eta_{C H P, h}=\frac{E_{h, \text { prod }}}{E_{b g, C H P}}$

The efficiency of biomethane production was used by Eastern Research Group 2011. This is defined in equation 13 :

$\eta_{b m}=\frac{E_{b m}}{E_{b g, u p}+E_{h, p a r, u p}+E_{e l, p a r, u p}}$

where $\mathrm{E}_{\mathrm{bg}, \mathrm{up}}$ is the energy content of biogas going to upgrading (MWh).

\subsubsection{Comparing biogas production to other energy production methods}

An output-input ratio including the energy content of feedstock can be applied to compare biogas production to other energy production uses of feedstocks. Cao \& Pawlowski 2012 used the calorific value of feedstock, but in this paper, the calculation is made using the lower heating value of dry material $\left(\mathrm{LHV}_{\mathrm{d}}\right)$. In addition to the energy content of feedstock, the energy needed for the biogas production system is included in the input.

$R_{f}=\frac{E_{h, s}+E_{b m}+E_{e l, s}}{\sum_{i=1}^{n} m_{i, T S} * L H V_{d, i}+E_{e l, o}+E_{f, b g}+E_{h, o}}$

where $\mathrm{E}_{\mathrm{f}, \mathrm{bg}}$ is the fuel used for producing the heat needed for biogas production.

Another metric for comparing biogas production to other energy recovery technologies is net output energy in relation to TS mass of feedstock (MJ/kg $/ \mathrm{kS}_{\mathrm{TS}}$ ). A similar method has been previously used by Horttanainen et al. 2009.

$F_{O / T S}=\frac{E_{h, s}+E_{b m}+E_{e l, s}-E_{f, b g}-E_{e l, o}-E_{h, o}}{\sum_{i=1}^{n} m_{i, T S}}$

\subsection{Kymen Bioenergy biogas plant}

These energy performance calculation methods are applied using data from an existing full-scale biogas plant in Finland in order to demonstrate and evaluate their use. Kymen Bioenergy (KB) biogas plant is located in the southwest in Kouvola and is near a waste water treatment plant (WWTP). The biogas plant uses sewage sludge and biowaste from industry, food industry and households; and uses grass from nearby farms. The plant is 
thermophilic $\left(53-57^{\circ} \mathrm{C}\right)$, and digestion takes place in approximately 17 days. The designed annual capacity of the biogas plant is $19000 \mathrm{t} / \mathrm{a}$, resulting in biogas with an energy content of $14000 \mathrm{MWh} \mathrm{a}^{-1}$ and $8700 \mathrm{t} \mathrm{a}^{-1}$ dewatered residue. The data from the $\mathrm{KB}$ biogas plant is from 2012, and the energy consumption and production values are derived from the energy use and demand measurements collected from there (Räsänen, 2013). Table 2 presents the masses of the feedstock utilized in the KB plant.

Table 2. Feedstocks to and residues from KB biogas plant.

\begin{tabular}{lcccccccc}
\hline & $\begin{array}{l}\text { Feedstocks } \\
\text { Sewage } \\
\text { sludge }\end{array}$ & Biowaste & Grass & Total & $\begin{array}{l}\text { Residues } \\
\text { Dewatered } \\
\text { digestate }\end{array}$ & $\begin{array}{l}\text { Fresh } \\
\text { digestate }\end{array}$ & Reject & Total \\
\hline TS \% & 20 & 32 & 28 & & 25 & 8 & n.a & \\
\hline Month & t/a & t/a & t/a & t/a & t/a & t/a & t/a & t/a \\
\hline 1 & 742 & 603 & 12 & 1357 & 371 & 0 & 54 & 425 \\
2 & 162 & 665 & 24 & 851 & 422 & 0 & 67 & 489 \\
3 & 288 & 885 & 14 & 1187 & 554 & 0 & 109 & 663 \\
4 & 115 & 692 & 18 & 825 & 605 & 9 & 68 & 682 \\
5 & 125 & 650 & 0 & 775 & 559 & 361 & 51 & 972 \\
6 & 93 & 488 & 0 & 581 & 505 & 183 & 52 & 740 \\
7 & 118 & 435 & 0 & 553 & 463 & 0 & 51 & 514 \\
8 & 87 & 506 & 0 & 592 & 488 & 142 & 42 & 672 \\
9 & 294 & 563 & 0 & 857 & 419 & 29 & 52 & 500 \\
10 & 206 & 737 & 0 & 943 & 601 & 25 & 69 & 694 \\
11 & 78 & 775 & 0 & 852 & 588 & 0 & 83 & 672 \\
12 & 252 & 530 & 0 & 782 & 500 & 841 & 52 & 1393 \\
\hline Total & 2560 & 7528 & 67 & 10156 & 6076 & 1589 & 750 & 8415 \\
1 & & & & & & &
\end{tabular}

KSS Energy uses the produced biogas on site in two ways. First, the energy plant uses the biogas in a gas engine to produce electricity and heat. Second, it uses it by upgrading and inserting it into a natural gas grid destined for vehicle fuel. A Jembacher gas motor is used for producing electricity and heat (capacity $1775 \mathrm{~kW}$ fuel, $755 \mathrm{~kW}$ electricity and $773 \mathrm{~kW}$ heat). In addition, there is a $1 \mathrm{MW}$ natural gas boiler for producing heat. A gas flare can be used for emergency gas handling (Räsänen, 2013).

Information concerning the biogas production yields and $\mathrm{LHV}_{\mathrm{d}}$ was obtained from the literature. In this study, the methane yields were assumed to be $250-320 \mathrm{~m}^{3} / \mathrm{t}_{\mathrm{TS}}$ for grass (Lehtomäki, 2006), 379-454 $\mathrm{m}^{3} / \mathrm{t}_{\mathrm{TS}}$ for biowaste (Lehtomäki et al., 2007) and 232-412 $\mathrm{m}^{3} / \mathrm{t}_{\mathrm{TS}}$ for sewage sludge (Ward et al., 2008; Lehtomäki et al., 2007). The lower heating value of the dry material $\left(\mathrm{LHV}_{\mathrm{d}}\right)$ of the feedstock was assumed to be $15-21.7 \mathrm{MJ} / \mathrm{kg}$ for sewage sludge (Houdková et al., 2008; Metcalf and Eddy, 2003), 12.5-18.6 MJ/kg for biowaste (Tchobanoglous et al., 1993; Sanchez et al., 2009) and $17.3 \mathrm{MJ} / \mathrm{kg}$ for grass (Nizami et al., 2009).

In addition, the energy demand for obtaining the feedstocks, transporting digestate and reject, and spreading of digestate were calculated using the following 2012 data and assumptions from the literature. The sludge came to the KB plant from the nearby waste water treatment plant, so no transport was needed. The fuel demand of grass cultivation and harvesting was assumed to be $1900 \mathrm{MJ} / \mathrm{t}_{\text {dry }}$ (Berglund and Börjesson, 2006), the 
transportation distance $20 \mathrm{~km}$, the capacity of the grass trailer $20 \mathrm{t}$ and the energy demand of a tractor $7 \mathrm{MJ} / \mathrm{km}$ (Lipasto, 2012). The biowaste used at the KB plant was collected by compacting waste trucks, each having a capacity of 4.3-8 $\mathrm{t}$ biowaste. It was collected on an average $150 \mathrm{~km}$ collection route, and the energy used was $7.2 \mathrm{MJ} / \mathrm{km}$ (Lipasto, 2012). The compacting waste trucks also transported part of the biowaste directly to the biogas plant. In addition, some of the biowaste was transported from waste management centers by a full trailer combination truck with a capacity of $33 \mathrm{t}$ biowaste and an energy use of $4.75 \mathrm{MJ} / \mathrm{km}$ (Lipasto, 2012). The digestate was transported $20 \mathrm{~km}$ on average to nearby farms by trucks with a capacity of $10 \mathrm{t}$ digestate and energy use of 7.2. $\mathrm{MJ} / \mathrm{km}$ (Lipasto, 2012). The energy consumption of spreading was $14 \mathrm{MJ} / \mathrm{t}$ for dewatered digestate and 17 $\mathrm{MJ} / \mathrm{t}$ for wet digestate. The reject was transported $14 \mathrm{~km}$ to the waste treatment center by a truck with a capacity for $10 \mathrm{t}$ reject, and this consumed $7.2 \mathrm{MJ} / \mathrm{km}$ of energy (Lipasto, 2012).

\section{Results}

\subsection{System boundaries}

Presented below in Figure 2 is a KB biogas plant-flow chart which includes the energy balance for the year 2012 as well as the system boundaries according to Figure 1. In 2012, the share of natural gas was $17 \%$ from the total energy content of biogas and natural gas used at the plant. Half of the biogas was used in CHP, and one third of it was upgraded. In addition, a great share of the biogas, $12 \%$, was flared, which resulted from problems with CHP and upgrading equipment in January and February of 2012.

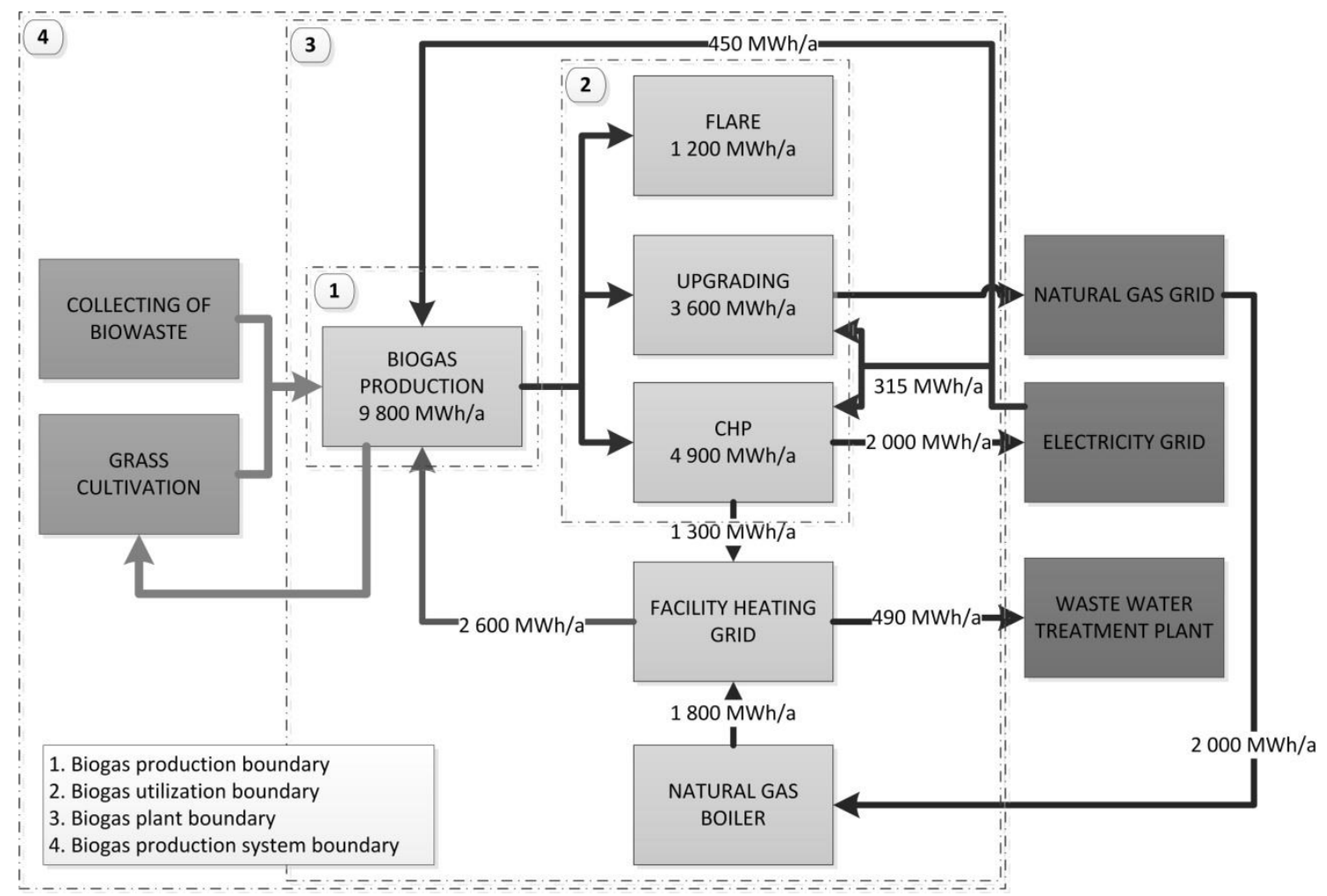

Figure 2. KB biogas plant energy balance for 2012 with the system boundaries 


\subsection{Energy balance of the KB biogas plant}

The monthly energy balance of the KB biogas plant for 2012 is presented in Table 3 . Seventy-two percent of the heat produced in the natural gas boiler was used in biogas production. The share of the natural gas heat from the total biogas plant parasitic heat was $48 \%$. This way, a greater share of the biogas was available for upgrading. Of the total energy into the biogas production system, natural gas corresponded to $59 \%$, the electricity use at the biogas plant to $23 \%$ and fuel use in biowaste collection and transport to $13 \%$. The rest of the energy input was mainly the energy use for digestate transport, $2 \%$, and the electricity used for biomethane compression, $2 \%$. The annual electricity use for biogas upgrading was approximately $190 \mathrm{MWh} / \mathrm{a}$, and the annual electricity use of CHP was $125 \mathrm{MWh} / \mathrm{a}$.

Table 3. The energy balance of KB biogas plant including biogas energy content, natural gas use, produced energy carriers, KB biogas plant parasitic electricity (el.) and heat demand, energy produced by CHP, heat delivered to the waste water treatment plant, fuel used for obtaining feedstock, fuel used for transporting residues and electricity used for pressurizing biomethane.

Table 3. The energy balance of KB biogas plant including biogas energy content, natural gas use, produced energy carriers, KB biogas plant parasitic electricity (el.) and heat demand, energy produced by CHP, heat delivered to the waste water treatment plant, fuel used for obtaining feedstock, fuel used for transporting residues and electricity used for pressurizing biomethane.

\begin{tabular}{|c|c|c|c|c|c|c|c|c|c|c|}
\hline \multirow[t]{3}{*}{ Month } & \multirow{3}{*}{$\begin{array}{l}\text { Biogas } \\
\text { MWh }\end{array}$} & \multirow{2}{*}{$\begin{array}{l}\text { Natural } \\
\text { gas }\end{array}$} & \multicolumn{2}{|c|}{ KB parasitic } & \multicolumn{2}{|l|}{$\mathrm{CHP}$} & \multirow{3}{*}{$\begin{array}{l}\text { WWTP } \\
\text { Heat } \\
\text { MWh }\end{array}$} & \multirow{3}{*}{$\begin{array}{l}\text { Feedstock } \\
\text { Fuel } \\
\quad \mathrm{MWh} \\
\end{array}$} & \multirow{3}{*}{$\begin{array}{l}\text { Residues } \\
\text { Fuel } \\
\text { MWh }\end{array}$} & \multirow{3}{*}{$\begin{array}{l}\text { Pressurizing } \\
\text { El. } \\
\quad \text { MWh }\end{array}$} \\
\hline & & & \multirow{2}{*}{$\begin{array}{l}\text { El. } \\
\text { MWh }\end{array}$} & \multirow{2}{*}{$\begin{array}{l}\text { Heat } \\
\text { MWh }\end{array}$} & \multirow{2}{*}{$\begin{array}{l}\text { El. } \\
\text { MWh }\end{array}$} & \multirow{2}{*}{$\begin{array}{l}\text { Heat } \\
\qquad \text { MWh }\end{array}$} & & & & \\
\hline & & MWh & & & & & & & & \\
\hline 1 & 784 & 333 & 59 & 242 & 3 & 27 & 85 & 33 & 6 & 5 \\
\hline 2 & 761 & 409 & 51 & 255 & 267 & 0 & 110 & 37 & 5 & 1 \\
\hline 3 & 1134 & 125 & 65 & 259 & 249 & 219 & 73 & 51 & 7 & 4 \\
\hline 4 & 870 & 95 & 53 & 218 & 276 & 177 & 44 & 39 & 8 & 3 \\
\hline 5 & 744 & 84 & 47 & 195 & 247 & 142 & 22 & 32 & 7 & 2 \\
\hline 6 & 821 & 26 & 50 & 211 & 210 & 206 & 18 & 28 & 11 & 3 \\
\hline 7 & 588 & 130 & 54 & 181 & 183 & 80 & 16 & 28 & 8 & 4 \\
\hline 8 & 703 & 117 & 70 & 166 & 84 & 79 & 18 & 32 & 6 & 8 \\
\hline 9 & 753 & 101 & 77 & 171 & 86 & 87 & 7 & 36 & 7 & 10 \\
\hline 10 & 865 & 175 & 88 & 232 & 85 & 88 & 14 & 47 & 8 & 12 \\
\hline 11 & 897 & 186 & 85 & 245 & 102 & 97 & 20 & 51 & 8 & 12 \\
\hline 12 & 866 & 177 & 65 & 261 & 223 & 162 & 60 & 34 & 6 & 4 \\
\hline Total & 9785 & 1958 & 765 & 2638 & 2015 & 1365 & 487 & 448 & 87 & 69 \\
\hline
\end{tabular}

\subsection{Output-input ratio calculation results}

Table 4 presents both the monthly output-input ratios and the annual output-input ratio for the $\mathrm{KB}$ biogas plant for 2012. The output-input ratios $\mathrm{R}_{\mathrm{pr} 2}, \mathrm{R}_{\mathrm{pl}}$ and $\mathrm{R}_{\mathrm{sy}}$ values were higher than one, which indicates that more energy was received out of the system than the parasitic energy need was for the system. The wider the system boundary is, the lower 
the output-input ratio is; in this system, the annual $R_{\text {sy }}$ was $44 \%$ lower than $R_{\text {pr2 }}$. $R_{\text {pr1 }}$ was lower than one because the plant's biogas yield did not reach those found in the literature.

Table 4. Output-input ratios of the KB biogas plant.

\begin{tabular}{|c|c|c|c|c|c|c|}
\hline \multirow[t]{2}{*}{ Month } & \multicolumn{3}{|c|}{ Biogas production } & \multirow{2}{*}{$\begin{array}{c}\text { Biogas } \\
\text { utilization } \\
\qquad \mathrm{R}_{\mathrm{ut}} \\
\end{array}$} & \multirow{2}{*}{$\begin{array}{c}\text { Biogas } \\
\text { plant } \\
\mathrm{R}_{\mathrm{pl}} \\
\end{array}$} & \multirow{2}{*}{$\begin{array}{l}\text { Biogas production } \\
\text { system } \\
\qquad \mathrm{R}_{\mathrm{sy}} \\
\end{array}$} \\
\hline & $\mathrm{R}_{\mathrm{pr} 1, \mathrm{MIN}}$ & $\mathrm{R}_{\mathrm{pr} 1, \mathrm{MAX}}$ & $\mathrm{R}_{\mathrm{pr} 2}$ & & & \\
\hline 1 & 0.3 & 0.7 & 2.8 & 0.3 & 0.9 & 0.8 \\
\hline 2 & 0.3 & 0.6 & 2.6 & 0.4 & 1.0 & 0.9 \\
\hline 3 & 0.3 & 0.7 & 3.8 & 0.6 & 2.8 & 2.1 \\
\hline 4 & 0.3 & 0.7 & 3.4 & 0.7 & 3.2 & 2.4 \\
\hline 5 & 0.3 & 0.7 & 3.2 & 0.7 & 2.9 & 2.2 \\
\hline 6 & 0.4 & 0.9 & 3.3 & 0.7 & 5.3 & 3.4 \\
\hline 7 & 0.3 & 0.8 & 2.7 & 0.8 & 2.3 & 1.9 \\
\hline 8 & 0.3 & 0.8 & 3.5 & 0.8 & 2.7 & 2.2 \\
\hline 9 & 0.3 & 0.7 & 3.6 & 0.9 & 3.4 & 2.6 \\
\hline 10 & 0.3 & 0.6 & 3.2 & 0.9 & 2.8 & 2.2 \\
\hline 11 & 0.3 & 0.7 & 3.2 & 0.9 & 2.8 & 2.2 \\
\hline 12 & 0.4 & 0.8 & 2.9 & 0.7 & 2.1 & 1.8 \\
\hline Annual & 0.3 & 0.7 & 3.2 & 0.7 & 2.3 & 1.8 \\
\hline
\end{tabular}

The annual $\mathrm{R}_{\mathrm{pr} 1}$ varied between $0.3-0.7$, whereas the $\mathrm{R}_{\mathrm{pr} 1}$ monthly values varied between $0.3-0.9$. The main reason for this substantial variation is the wide range of biogas yield values found from the literature (Lehtomäki, 2006) (Lehtomäki et al., 2007) (Seppälä et al., 2008). A narrower range of values could be obtained when the biogas yields were measured from the feedstocks used in the KB plant. The difference between monthly minimum and maximum values in relation to minimum values varied between $100-150 \%$ because of the change in the amounts of feedstock fed to the plant. The annual $\mathrm{R}_{\mathrm{pr} 2}$ was 3.2 (2.6-3.8), which means that the annual input energy was 30\% (26-39\%) of the biogas energy content.

It can be seen from the table that the calculated $R_{u t}$ was under 0.5 in January and February of 2012; this is due to the biogas loss in flare which occurred then, but the $R_{u t}$ value increased thereafter, reflecting that more of the biogas was directed to upgrading. It should be noted that if biogas is used only in electricity and heat production, the maximum value of $R_{u t}$ will be the sum of CHP electricity and heat efficiency. The share of biogas directed to upgrading has a significant effect on $\mathrm{R}_{\mathrm{ut}}$, which increases when the share of biogas directed to upgrading also increases. For January and February, both $R_{p l}$ and $R_{s y}$ were near or below one, which means that the energy output from the system was equal to or less than the energy received from the system. For the remainder of the year, both $R_{p l}$ and $R_{s y}$ were higher, and they peaked in June, when $R_{p l}$ was $130 \%$ higher and $R_{s y} 80 \%$ higher than the annual ratios. 


\subsection{The biogas plant's own energy consumption}

The parasitic energy demand and energy efficiencies were evaluated on an annual basis. The annual parasitic electricity demand in relation to the produced electricity $\mathrm{w}_{\mathrm{el}, \mathrm{par} 1}$ was $38 \%$, and in relation to the produced biogas $\mathrm{w}_{\mathrm{el}, \mathrm{par} 2}, 8 \%$. For parasitic heat, $\mathrm{w}_{\mathrm{h}, \mathrm{par} 1}$ was $193 \%$ and $\mathrm{wh}_{\mathrm{h}, \mathrm{par} 2}$ was $27 \%$. The $\mathrm{KB}$ biogas plant $\mathrm{CHP}$ annual gross electric efficiency for

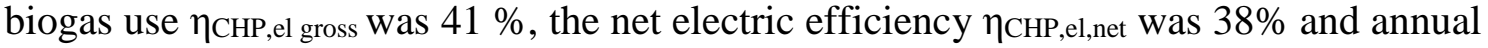
heat production efficiency $\eta_{\text {CHP, h }}$ was $28 \%$. The efficiency of biomethane production was $95 \%$.

\subsection{Biogas production values for comparison}

In the calculations for $\mathrm{F}_{\mathrm{O} / \mathrm{TS}}$ and $\mathrm{R}_{\mathrm{f}}$ for the $\mathrm{KB}$ biogas plant, the natural gas used for producing the heat supplied outside the biogas plant $\left(\mathrm{E}_{\mathrm{h}, \mathrm{s}}\right)$ was not included, as solely the performance of the system related to biogas production was under analysis. This means that $E_{h, s}$ was zero and $E_{f, b g}$ was equal to $E_{f}$ subtracted by the natural gas energy used to produce the $\mathrm{E}_{\mathrm{h}, \mathrm{s}}$. This means that only the natural gas energy used to produce the required heat for biogas plant operations was included. The calculated $\mathrm{R}_{\mathrm{bg}, \mathrm{f}}$ was $0.22-0.31$, depending on the minimum and maximum values of $\mathrm{LHV}_{\mathrm{d}}$. The resulting $\mathrm{F}_{\mathrm{O} / \mathrm{TS}}$ was annually $4 \mathrm{MJ} / \mathrm{kg}_{\mathrm{TS}}$, having its lowest value of $0 \mathrm{MJ} / \mathrm{kg}_{\mathrm{TS}}$ in January and February, and reaching its highest value of $7 \mathrm{MJ} / \mathrm{kg}_{\mathrm{TS}}$ in June.

\section{Discussion}

In an energy performance assessment of a biogas plant, one gains clearer results from using more than one system boundary. This is confirmed by the evaluation of energy performance of the KB biogas plant. The energy balance results of the plant show that energy production of the plant was at its lowest in January and February. The issue was not biogas production; this can be seen in the values of $R_{p r 1}$ and $R_{p r 2}$, which were of the same magnitude in January and February as they were for the rest of the year. The main problem stemmed from the utilization of biogas, as evidenced in the values of $R_{u t}, R_{p l}$ and $\mathrm{R}_{\mathrm{sy}}$, which were significantly lower in January and February than for the rest of the year.

The values of $\mathrm{R}_{\mathrm{pr} 1}$ for the $\mathrm{KB}$ biogas plant demonstrate that the biogas production potentials calculated using the biogas yields from the literature resulted in a wide range of values, 0.3-0.95. Schievano et al. 2011 found that the biomethane yield, which is similar to $\mathrm{R}_{\mathrm{pr} 1}$, varied between $0.84-0.93$ for the three plants they evaluated. Calculated $\mathrm{R}_{\text {pr1 }}$ values from the KB biogas plant were mainly lower than results reported by Schievano et al. 2011, but the calculated range of $R_{p r 1}$ is within the range of their values. On the other hand, Djatkov et al. 2012 have calculated even higher values for the relative biogas yield, $90-161 \%$.

The output-input ratios found from the literature had a range of 1.8-13.1, as can be seen from Table 1. The wide range indicates that biogas production chain can be established in various ways. The aim of $\mathrm{R}_{\mathrm{sy}}$ is to provide evaluation on energy performance of these chains. The $2012 \mathrm{R}_{\mathrm{sy}}$ of the KB biogas plant was 1.8 annually and reached its highest value, 3.8 , in June. This means that the values calculated in this study are at the lower end 
of that range. Although studies found from the literature mainly deal with crop- based biogas production systems, study conducted by Berglund \& Börjesson 2006 also included biowaste as a feedstock. The output-input ratio range calculated from their results is $1.25-$ 5 , which is closer to the values found in this study.

The results calculated for parasitic energy demand and efficiencies in this study are comparable to the values presented in literature. Banks et al. 2011 found that the electricity use of the biogas plant was $30.4 \%$ in relation to the energy content of the produced biogas when the biogas was used in the CHP. This is similar to the annual wel,par1 of the KB biogas plant without the biogas upgrading, which was $29 \%$. For the KB biogas plant, the $\mathrm{wel}_{\mathrm{el}, \mathrm{par}} \mathrm{was} 5.9 \%$ without the biogas upgrading and $8 \%$ with biogas upgrading, both values being higher than the range of $0.25-4.47 \%$ found by Laaber et al., 2007 . Total electricity and heat efficiency (the sum of $\eta_{\mathrm{CHP}, \mathrm{el} \text {,net }}$ and $\eta_{\mathrm{CHP}, \mathrm{h}}$ ) of the KB biogas plant was 66\%, which is higher than the median value found by Laaber et al. 2007, 47.8\%, but within the range they present, $30.5-73 \%$. The proportioning to the energy content of the produced biogas $\left(\mathrm{w}_{\mathrm{el}, \mathrm{par} 2}\right)$ is a more useful metric in those cases where a biogas plant produces other energy carriers in addition to or instead of electricity and heat. It should be borne in mind that comparison of the parasitic energy demand and efficiencies to literature values require that differences between studies are carefully considered.

The indirect energy use of producing materials and fuels was excluded from this study as well as the indirect energy savings from utilizing digestate as fertilizer. However, using biowaste and sewage sludge-based digestate on fields instead of mineral fertilizers would indeed reduce the energy need in fertilizer production. The digestate energy content was also excluded from the calculations, but the digestate might be suitable for incineration after dewatering, which would improve output-input ratios. However, often the drying need before incineration makes the energy recovery from digestate unfeasible. It should be noted that indirect energy use and energy savings are useful in calculating the energy pay-back time of biogas production.

Deriving the exact value for biogas production performance, $R_{\mathrm{pr} 1}$, is challenging. The reason for this is that in most cases, literature values have to be used for biogas yields. In addition, the $\mathrm{R}_{\mathrm{pr} 1}$ calculated with values for produced biogas and masses fed to the plant taken from the same time period might be different from the actual value of $R_{p r l}$, since the hydraulic retention time is not taken into account in the calculation. For example, if $\mathrm{R}_{\mathrm{pr} 1}$ is estimated for one month, part of the masses that produced the biogas in the estimated month have already been fed to the plant in the previous month, and part of the masses have been fed to the plant at the end of the month, only to produce biogas in the next month. Therefore, the absolute value for how efficiently the biogas reactor is utilizing the feedstock is difficult to arrive at, but the changes in the value of $R_{\text {pri }}$ over time could be used for indicating the performance of biogas production. If $R_{p r 1}$ is low over an extended period of time, it could indicate that some corrections should be made to the biogas reactor conditions. Correspondingly $\mathrm{R}_{\mathrm{pr} 2}$ can be used in estimating the need for changes in reactor conditions.

$\mathrm{R}_{\mathrm{pl}}$ provides an overall value for the energy performance of a biogas plant that can be used on monthly or yearly basis to monitor the existing plant performance. This should be relatively easy to calculate since measurements for the used and produced energy in 
the plant are usually already in place at the plant. $R_{\mathrm{pl}}$ is not very suitable for daily basis analysis, since it does not yield any information on specific parts of the plant, nor is it suitable for adjusting the plant parameters. $R_{\mathrm{pl}}$ could be also used in preliminary calculations during the planning phase of a biogas plant to see whether the designed plant could deliver more energy than it consumes. However, the disadvantage of $R_{p l}$ is that when there is a change in it, it does not indicate where the change has occurred in the plant.

$\mathrm{R}_{\mathrm{sy}}$ is the most comprehensive of all the output-input ratios defined in this paper, and it is useful for comparing the energy performance of different biogas production systems. In an energy use assessment, the $\mathrm{R}_{\text {sy }}$ includes the related processes outside the biogas plant. The collection and transport of biowaste as well as the cultivation, harvesting and transport of grass are included. This allows an examination of the overall energy performance of a biogas production system and indicates whether there still is some energy gain obtained from the system. $R_{\text {sy }}$ may be the most difficult value to calculate. Biogas plant operators might not have a clear picture of the energy used in the processes occurring outside the plant. In particular, biowaste collection energy consumption information is difficult to obtain, even from waste management companies, and assumptions therefore have to be made. Similarly, estimating the amount of energy used in the cultivation and harvesting of energy crops requires using average numbers in the calculations. $\mathrm{R}_{\text {sy }}$ can be used in the planning phase of biogas production to estimate how much energy may be consumed in the obtaining of the feedstock and the treatment of residues in light of the goal of producing more energy from the system than is consumed by the system.

Comparing $\mathrm{R}_{\mathrm{sy}}$ and $\mathrm{R}_{\mathrm{pl}}$ results is also useful, since this can yield information concerning where energy performance could be most improved. If $R_{\text {sy }}$ is significantly lower than $R_{p l}$, then energy performance of the biogas production could be improved by cutting down the energy demand of the obtaining of the feedstock or transport and treatment of the residues. If, on the other hand, $\mathrm{R}_{\mathrm{pl}}$ is almost equal to $\mathrm{R}_{\mathrm{sy}}$, then a greater impact on the energy performance can be achieved with actions implemented within the biogas plant. The annual $\mathrm{R}_{\text {sy }}$ was 1.8 and annual $\mathrm{R}_{\mathrm{pl}}$ was 2.3 for the $\mathrm{KB}$ biogas plant, results which are quite close to each other. The main reason accounting for the difference is the energy consumption in biowaste collection and transport. In addition, the $\mathrm{R}_{\mathrm{pl}}$ and $\mathrm{R}_{\mathrm{sy}}$ values are greatly affected by the amount of fuel supplied to the biogas plant from outside the plant. The $\mathrm{R}_{\mathrm{pl}}$ and $\mathrm{R}_{\mathrm{sy}}$ values of the KB biogas plant were much higher in June, when the natural gas consumption is low. This means that if it had utilized its own biogas energy, the plant's output-input ratios would have been higher. However, in the case of the KB biogas plant, less biomethane could be produced.

The lack of comparable data on the energy efficiency of biogas plants makes it difficult to evaluate different biogas production plants and production systems. This might be the case in the purchasing and/or operating of a biogas plant. For an operating existing plant, sufficient measurements must be in place in order for energy performance evaluations to be made. The output-input ratio equations, parasitic energy ratio equations and energy efficiency equations presented in this study aim to offer additional tools for comparison of biogas production systems and plants. 


\section{Conclusions}

There is a wide range of methods available for calculating the energy performance of biogas production system or parts of it. To evaluate these various methods, four different system boundaries for biogas production system was defined, equations formed and data from an existing biogas plant used. Rather than inventing new methods this study focused on the existing methods and their merits and a

imed at showing how they could be used to get more consistent results in future applying also the system boundary thinking. From the estimated methods, the output-input ratio $(\mathrm{R})$ is the most useful for evaluating the biogas production energy performance. $R_{\text {pr1 }}$ and $R_{\mathrm{pr} 2}$ can be used for following the performance of biogas reactor while comparing these to $\mathrm{R}_{\mathrm{ut}}$ allows identifying the reason for possible low performance of the biogas plant. $\mathrm{R}_{\mathrm{pl}}$ provides assessment of biogas plant and comparing it with $R_{\text {sy }}$ indicates whether it would be useful to concentrate on energy consumption of upstream processes or on the parasitic energy demand of the plant to improve biogas system energy performance. In general, the comparability of the energy performance of various biogas plants and systems requires that the energy performance is calculated in a more consistent manner.

\section{Acknowledgements}

This work was financially supported by Finnish Foundation for Technology Promotion.

\section{References}

Banks, C., Chesshire, M., Heaven, S., and Arnold, R. (2011). Anaerobic digestion of source-segregated domestic food waste: Performance assessment by mass and energy balance. Bioresour. Technol., 102, pp. 612-620.

Berglund, M. and Börjesson, P. (2006). Assessment of energy performance in the lifecycle of biogas production. Biomass Bioenergy, 30, pp. 254-266.

Cao, Y. and Pawlowski, A. (2012). Sewage sludge-to-energy approaches based on anaerobic digestion and pyrolysis: Brief overview and energy efficiency assessment. Renewable Sustainable Energy Rev., 16, pp. 1657-1665.

Davis, S.C., Anderson-Teixeira, K.J., and DeLucia, E.H. (2009). Life-cycle analysis and the ecology of biofuels. Trends Plant Sci., 14, pp. 140-146.

Djatkov, D., et al. (2012). New method for assessing the performance of agricultural biogas plants. Renewable Energy, 40, pp. 104-112.

Eastern Research Group (2011). Protocol for quantifying and reporting the performance of anaerobic digestion systems for livestock manures.

Eurostat (2011). Share of renewables in the EU27 energy supply almost doubled between 1999 and 2009. [Retrieved], url: http://europa.eu/rapid/pressReleasesAction.do?reference=STAT/11/53\&format=HT M.

Gerin, P.A., Vliegen, F., and Jossart, J.-M. (2008). Energy and CO2 balance of maize and grass as energy crops for anaerobic digestion. Bioresour. Technol., 99, pp. 2620-2627.

Gropgen (2007). An overall energy balance for energy production taking into account energy inputs associated with farming. University of Vienna. 
Horttanainen, M., Luoranen, M., Niskanen, A., and Havukainen, J. (2009). On the criteria of treatment method selection for biodegradable waste between combustion and anaerobic digestion. Twelfth International Waste Management and Landfill Symposium. S. Margherita di Pula, Cagliari, Italy, 5 - 9 October 2009.

Houdková, L., et al. (2008). Thermal processing of sewage sludge - II. Appl. Therm. Eng., 28, pp. 2083-2088.

Laaber, M., Madlener, R., Kirchmayr, R., and Braun, R. (2007). Aufbau eines Bewertungssystems für Biogasanlagen - "Gütesiegel Biogas".

Lacour, S., et al. (2012). Energy and environmental balance of biogas for dual-fuel mobile applications. Renewable Sustainable Energy Rev., 16, pp. 1745-1753.

Lehtomäki, A. (2006). Biogas production from energy crops and crop residues. Jyväskylä: University of Jyväskylä.

Lehtomäki, A., Paavola, T., Luostarinen, S., and Rintala, J. (2007). Biokaasusta energiaa maatalouteen - raaka-aineet, teknologiat ja lopputuotteet (in Finnish). Jyväskylä University.

Lipasto (2012). Liikenteen päästöt (in Finnish). [Retrieved], url: http://lipasto.vtt.fi/.

Metcalf and Eddy (2003). Wastewater engineering - treatment, disposal and reuse, 4th edn. New York: McGraw Hill.

Murphy, J., Weiland, P., Braun, R., and Wellinger, A. (2011). Biogas from crop digestion. IEA Bioenergy Task 37.

Navickas, K., et al. (2012). Influence of different biomass treatment technologies on efficiency of biogas production. 11th International Scientific Conference Engineering for Rural Development 24.-25.05.2012 Jelgava, Latvia.

Nizami, A.-S., Korres, N.E., and Murphy, J.D. (2009). Review of the integrated process for the production of grass biomethane. Environ. Sci. Technol., 43, pp. 8496-8508.

Patterson, M.G. (1996). What is energy efficiency? Concepts, indicators and methodological issues. Energy Policy, 24, pp. 377-390.

Poeschl, M., Ward, S., and Owende, P. (2012). Environmental impacts of biogas deployment e Part II: life cycle assessment of multiple production and utilization pathways. J. Cleaner Prod., 24, pp. 184-201.

Pöschl, M., Ward, S., and Owende, P. (2010). Evaluation of energy efficiency of various biogas production and utilization pathways. Appl. Energy, 87, pp. 33053321.

Prade, T., Scensson, S.-E., and Mattsson, J.E. (2012). Energy balances for biogas and solid biofuel production from industrial hemp. Biomass Bioenergy, 40, pp. 36-52.

Räsänen, K. (2013). Facility Manager. KSS Energy E-mails: 20.3.2012-23.1.2013.

Salter, A. and Banks, C.J. (2009). Establishing an energy balance for crop-based digestion. Water Sci. Technol., 59, pp. 1053-1060.

Salter, A., et al. (2005). Establishing an energy balance for crop-based digestion energy. 14th European Biomass Conference and Exhibition: Biomass for Energy, Industry and Climate Protection, Paris, France, 17 - 21 Oct 2005. 
Sanchez, M.E., Otero, M., Gómez, X., and Morán, A. (2009). Thermogravimetric kinetic analysis of the combustion of biowastes. Renewable Energy, 34, pp. 16221627.

Schievano, A., D'Imporzano, G., Orzi, V., and Adani, F. (2011). On-field study of anaerobic digestion full-scale plants (Part II): New approaches On-field study of anaerobic digestion full-scale plants (Part II): New approaches. Bioresour. Technol., 102, pp. 8814-8819.

Seppälä, M., et al. (2008). Biogas from energy crops - optimal pre-treatments and storage, co-digestion and energy balance in boreal conditions. Water Sci. Technol., 58, pp. 1857-1863.

Tanaka, K. (2008). Assessment of energy efficiency performance measures in industry and their application for policy. Energy Policy, 36, pp. 2887-2902.

Tchobanoglous, G., Theisen, H., and Vigil, S. (1993). Integrated solid waste management. New York: McGraw Hill.

Tuomisto, H.L. and Helenius, J. (2008). Comparison of energy and greenhouse gas balances of biogas with other transport biofuel options based on domestic agricultural biomass in Finland. Agric. Food Sci., 17, pp. 240-251.

Uellendahl, H., et al. (2008). Energy balance and cost-benefit analysis of biogas production from perennial energy crops pretreated by wet oxidation. Water Sci. Technol., 58, pp. 1841-1847.

Ward, A.J., Hobbs, P.J., Holliman, P.J., and Jones, D.L. (2008). Optimisation of the anaerobic digestion of agricultural resources. Bioresour. Technol., 99, pp. 79287940 . 